American Journal of Agricultural and Biological Sciences 5 (3): 269-273, 2010

ISSN 1557-4989

(C) 2010 Science Publications

\title{
Effects of Machine-Induced Soil Compaction on Growth and Yield of Sugarcane
}

\author{
Prathuang Usaborisut and Tanya Niyamapa \\ Department of Agricultural Engineering, Faculty of Engineering at Kamphaengsaen, \\ Kasetsart University, Kamphaengsaen Campus, Nakhonpathom 73140, Thailand
}

\begin{abstract}
Problem statement: Sugarcane is one of the main economic crops in Thailand. After planting, it can be harvested annually for several successive ratoon crops. Recently, soil compaction due to mechanization has been recognized as a serious problem in sugarcane production. Therefore, this study aimed to clarify the effects of soil compaction on the growth and yield of sugarcane. Approach: The field experiments were conducted in loamy soil using a Randomized Complete Block Design (RCBD) with four treatments of soil compaction prepared by $0,5,15$ and 20 numbers of wheel passages of a tractor. Results: The results showed that soil compaction had significant effects on both the growth and yield of sugarcane, with the exceptions of tillering and Brix. The greatest reduction in yield compared with the control field was $22.9 \%$, which resulted from compacting with 15 tractor passages. The influence of block or furrow irrigation was indicated by the positive effect that higher watering had on minimizing the impact of soil compaction on the growth of sugarcane. Conclusion: Effects of soil compaction on growth and yield of sugarcane were clarified to some extent.
\end{abstract}

Key words: Soil compaction, sugarcane, growth, yield, tractor

\section{INTRODUCTION}

Sugarcane is one of the most important crops in Thailand today. In 2008, Thailand produced about 73 million tons of sugarcane with a production area of about one million hectares, which ranked third among world producers, after Brazil and China (CAI, 2008). In addition to being a food crop, sugarcane is an efficient crop for producing fuel ethanol. In some parts of the world, alcohol has traditionally been produced as a byproduct of the sugar industry, through the fermentation of molasses and subsequent distilling. However, juice extracted from cane can also be fermented directly and the products then distilled to produce fuel alcohol. In the past, manual harvesting was popular due to its low cost, low soil compaction and low damage to cane roots and the subsequent ratoon crop. Recently, due to labor shortages, mechanization has been implemented. There are between eight to ten tillage operations for conventional land preparation, while some areas have higher numbers up to 18. High numbers of traffic passes are also used in Thailand, with 13 passes being observed for conventional tillage treatment (Grange et al., 2005). As farm tractors and field equipment become larger and heavier, there is growing concern about soil compaction. Heavy equipment and tillage implements can cause damage to the soil structure. Soil structure is important to enable soil to hold and conduct the water, nutrients and air that are necessary for plant root activity. Soil compaction increases bulk density and soil strength (which restricts the rooting ability of the crop) and decreases porosity and the water infiltration rate. Alakukku and Elonen (1995) studied the long-term effects of compaction on yield and nitrogen uptake in clay and organic soils and reported that the mean result of the first eight years indicated that the compaction of clay soil from four passes reduced the yields by $4 \%$ and the nitrogen uptake of the annual crop by $9 \%$. Ngunjiri and Siemens (1995) also reported that maize yield following compaction over the entire plot area averaged $9.8 \mathrm{t} \mathrm{ha}^{-1}$, which was significantly lower than yields from no compaction, compaction between rows and compaction on the rows, which averaged 12.5, 12.6 and $12.6 \mathrm{tha}^{-1}$, respectively. In addition, the impact of soil compaction was apparent in seed emergence and root growth. Nasr and Selles (1995) found that the number of seedlings emerging and the speed of emergence were affected by bulk density, the aggregate size of seedlings and by the interaction of both variables. Although much research has been conducted on soil compaction and its effects on yield, it is difficult to estimate an economic impact because fields vary in soil type, crop rotation

Corresponding Author: Prathuang Usaborisut, Department of Agricultural Engineering,

Faculty of Engineering at Kamphaengsaen, Kasetsart University, Kamphaengsaen Campus, Nakhonpathom 73140, Thailand Tel/Fax: +6634-351896 
and weather conditions. For sugarcane, where soil compaction is recognized as one of the serious problems, there has been little research conducted to clarify the effect, or to examine the relationships between soil degradation and crop yield. Therefore, this research work intended to clarify the effects of machine-induced soil compaction on the growth and yield of sugarcane planted in central Thailand.

\section{MATERIALS AND METHODS}

Field tests were conducted on land owned by the Department of Agricultural Engineering, Nakhonpathom, Thailand. The soil was a loam, composed of $40.07 \%$ sand, $42.50 \%$ silt and $17.43 \%$ clay. The plastic limit and liquid limit were $17.46 \%$ and $24.9 \%$, respectively, with maximum compactability of $1.8 \mathrm{~kg} \mathrm{~m}^{-3}$ at $12.5 \%$ moisture content. The experiment was conducted using a Randomized Complete Block Design (RCBD) with four treatments of soil compaction in four blocks. Blocks were arranged to avoid any effects from land slope and furrow irrigation. The test procedure involved preparing the land, growing the sugarcane, determining the growth and measuring the final yield of sugarcane. The test area was plowed by disk plow to a depth of $35 \mathrm{~cm}$, followed by rotary tilling. A field of $60 \times 100 \mathrm{~m}^{2}$ was divided into sixteen plots each $15 \times 25 \mathrm{~m}^{2}$.

Before compacting the soil in the field, soil compaction was investigated in the sugarcane fields around the test site; mean bulk densities ranged between 1.51 and $1.75 \mathrm{~kg} \mathrm{~m}^{-3}$ in fields of first ratoon to fields of third ratoon. The bulk density of soil sampled from the inter-rows of sugarcane was higher than for samples taken in-row, which confirmed the effect of machine traffic over the years. In addition, it was found that the bulk density was greater at deeper zones within the soil profile.

Pretesting of the field soil compaction was conducted. A MF390 tractor weighing $3500 \mathrm{~kg}$ with a tire inflation pressure of 1.27 bar was used to compact the soil. Twenty passages of the tractor were completed on the same path. Soil bulk densities were sampled and results are shown in Fig. 1.

As shown in Fig. 1, bulk density increased with the number of passages. The bulk density increased at a greater rate in the first few passes and then at a more constant rate. This phenomenon is normally observed in soil compaction. Based on the pretest results, soil compaction on the experimental plots was carried out at four levels of compaction with 0 (control plot), 5, 15 and 20 passes of the tractor, respectively. Test plots were randomly selected in each block and compacted accordingly.

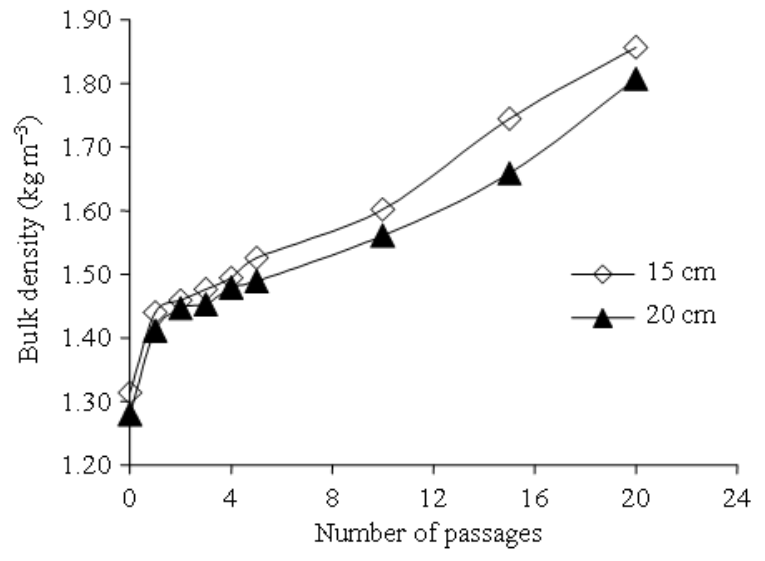

Fig. 1: Relationship between number of passages and bulk density of the soil at depths of 15 and $20 \mathrm{~cm}$

After completing land preparation, sugarcane was planted in the field. The sugarcane cultivar used was K84-200, which is the dominant cultivar planted in the west, central and lower north areas of Thailand. Water was applied by furrow irrigation, which is a popular method for sugarcane production. However, a disadvantage of this method is that there is no uniform watering from the head to the end of the furrow. Therefore, the experimental design had to be set up in blocks that avoided the effects of furrow irrigation. Block 1 was located near a canal. The diameter and height of stalks, tillering and Brix were recorded to assess treatment effects and final yield was measured.

\section{RESULTS}

Height of sugarcane: Twenty samples of stalks were randomly chosen from the central zone of each plot to avoid any influence from adjacent plots. The stalk height was measured up to the top visible dewlap. The average tallest cane was $382.1 \mathrm{~cm}$ found at age 12 month in plots with 0 Number of passage Compaction $(\mathrm{NpC})$. The lowest average height was $9.3 \mathrm{~cm}$ found at age 1 month in plots with $20 \mathrm{NpC}$. All results are listed in Table 1.

The tallest sugarcane in the field for every month of measurement was with $0 \mathrm{NpC}$. In the first month, there was no difference among the average heights, except for the plots with $20 \mathrm{NpC}$. From the third month, the height of canes in the plots with $20 \mathrm{NpC}$ seemed to be comparatively higher than in the plots with 5 and $10 \mathrm{NpC}$. The height of sugarcane after 12 month in the plots with $0 \mathrm{NpC}$ was significantly different and about $10 \mathrm{~cm}$ higher than in plots with 15 $\mathrm{NpC}$. 
Am. J. Agri. \& Biol. Sci., 5 (3): 269-273, 2010

Table 1: Average height of sugarcane in plots with different soil compaction treatments Height at month $(\mathrm{cm})$

\begin{tabular}{|c|c|c|c|c|c|c|c|c|c|c|c|c|}
\hline $\mathrm{NpC}$ & 1 & 2 & 3 & 4 & 5 & 6 & 7 & 8 & 9 & 10 & 11 & 12 \\
\hline$\overline{0}$ & $10.7 \mathrm{a}$ & $25.8 \mathrm{a}$ & $112.4 \mathrm{a}$ & $149.9 \mathrm{a}$ & $190.7 \mathrm{a}$ & $235.4 a$ & $305.9 a$ & $341.1 \mathrm{a}$ & $360.1 \mathrm{a}$ & $361.7 a$ & $371.9 \mathrm{a}$ & $382.1 \mathrm{a}$ \\
\hline 5 & $10.4 \mathrm{a}$ & $21.3 b$ & $106.0 \mathrm{~b}$ & $141.8 b$ & $182.7 \mathrm{~b}$ & $229.1 b$ & $294.9 b$ & $326.9 b$ & $344.6 b$ & $351.5 b$ & $361.7 b$ & $372.4 b$ \\
\hline 15 & $10.2 \mathrm{a}$ & $20.8 b$ & $98.2 \mathrm{c}$ & $134.6 \mathrm{c}$ & $174.7 \mathrm{c}$ & $218.9 \mathrm{c}$ & $292.2 b$ & $329.8 b$ & $349.7 b$ & $352.7 b$ & $362.3 b$ & $372.5 b$ \\
\hline 20 & $9.3 b$ & $20.5 b$ & $111.3 \mathrm{a}$ & $147.9 \mathrm{a}$ & $190.2 \mathrm{a}$ & $233.5 \mathrm{ab}$ & $296.0 b$ & $323.8 b$ & $347.2 b$ & $358.4 \mathrm{ab}$ & $368.3 \mathrm{ab}$ & $378.7 \mathrm{ab}$ \\
\hline F-ratio & $* *$ & ** & $* *$ & $* *$ & $* *$ & $* *$ & $* *$ & $* *$ & $* *$ & $*$ & $*$ & $*$ \\
\hline
\end{tabular}

Note: Figures in the same column followed by the same lower case letter are not significantly different analyzed by Duncan's Multiple Range Test (DMRT) at $95 \%$ significance. *: Significant at $95 \%$; **: Significant at $99 \%$

Table 2: Average height of sugarcane by block

\begin{tabular}{|c|c|c|c|c|c|c|c|c|c|c|c|c|}
\hline \multirow[b]{2}{*}{ Block } & \multicolumn{12}{|c|}{ Height at month $(\mathrm{cm})$} \\
\hline & 1 & 2 & 3 & 4 & 5 & 6 & 7 & 8 & 9 & 10 & 11 & 12 \\
\hline 1 & $10.1 \mathrm{a}$ & $22.1 b$ & $127.0 \mathrm{a}$ & $167.9 \mathrm{a}$ & $216.9 a$ & $266.0 \mathrm{a}$ & $328.3 a$ & $357.0 \mathrm{a}$ & $373.5 \mathrm{a}$ & $377.3 \mathrm{a}$ & $387.0 \mathrm{a}$ & $397.5 a$ \\
\hline 2 & $10.2 \mathrm{a}$ & $22.1 b$ & $106.1 \mathrm{~b}$ & $145.2 \mathrm{~b}$ & $187.9 \mathrm{~b}$ & $235.1 b$ & $308.6 b$ & $347.0 \mathrm{~b}$ & $360.0 \mathrm{~b}$ & $368.3 b$ & $378.0 \mathrm{~b}$ & $388.4 \mathrm{~b}$ \\
\hline 3 & $10.3 \mathrm{a}$ & $25.0 \mathrm{a}$ & $106.7 \mathrm{c}$ & $141.0 \mathrm{c}$ & $180.7 \mathrm{c}$ & $226.8 \mathrm{c}$ & $299.2 \mathrm{c}$ & $336.7 \mathrm{c}$ & $355.3 \mathrm{~b}$ & $361.4 \mathrm{~b}$ & $371.2 \mathrm{~b}$ & $381.5 b$ \\
\hline 4 & $10.0 \mathrm{a}$ & $19.0 \mathrm{c}$ & $90.0 \mathrm{~d}$ & $120.0 \mathrm{~d}$ & $151.8 \mathrm{~d}$ & $187.6 \mathrm{~d}$ & $252.9 \mathrm{~d}$ & $280.9 d$ & $309.3 \mathrm{c}$ & $320.6 c$ & $331.3 \mathrm{c}$ & $341.6 c$ \\
\hline F-ratio & ns & $* *$ & $* *$ & $* *$ & $* *$ & $* *$ & $* *$ & $* *$ & $* *$ & $* *$ & $* *$ & $* *$ \\
\hline
\end{tabular}

Note: Figures in the same column followed by the same lower case letter are not significantly different analyzed by DMRT at 95\% significance. ns: Not significant; **: Significant at $99 \%$

Table 3: Average number of tillers in plots with different soil compaction treatments

\begin{tabular}{|c|c|c|c|c|c|c|c|c|c|c|}
\hline \multirow[b]{2}{*}{$\mathrm{NpC}$} & \multicolumn{10}{|c|}{ Number of tillers at month } \\
\hline & 3 & 4 & 5 & 6 & 7 & 8 & 9 & 10 & 11 & 12 \\
\hline 0 & 1.70 & 1.49 & 1.27 & $1.42 \mathrm{~b}$ & $1.47 \mathrm{~b}$ & 1.67 & 1.73 & 1.68 & 1.72 & 1.75 \\
\hline 5 & 1.79 & 1.51 & 1.17 & $1.50 \mathrm{~b}$ & $1.85 \mathrm{a}$ & 1.85 & 1.89 & 1.82 & 1.82 & 1.82 \\
\hline 15 & 1.61 & 1.35 & 1.24 & $1.91 \mathrm{a}$ & $1.79 \mathrm{a}$ & 1.88 & 1.89 & 1.76 & 1.79 & 1.87 \\
\hline 20 & 1.99 & 1.56 & 1.39 & $1.40 \mathrm{~b}$ & $1.68 \mathrm{ab}$ & 1.74 & 1.78 & 1.78 & 1.84 & 1.82 \\
\hline F-ratio & ns & ns & ns & $*$ & $*$ & ns & ns & ns & ns & ns \\
\hline
\end{tabular}

Note: Figures in the same column followed by the same lower case letter are not significantly different analyzed by DMRT at $95 \%$ significance. ns: Not significant; *: Significant at $95 \%$

Table 4: Average stalk diameter of sugarcane in plots with different soil compaction treatments

\begin{tabular}{|c|c|c|c|c|c|c|c|c|}
\hline \multirow[b]{2}{*}{$\mathrm{NpC}$} & \multicolumn{8}{|c|}{ Stalk diameter at month $(\mathrm{cm})$} \\
\hline & 5 & 6 & 7 & 8 & 9 & 10 & 11 & 12 \\
\hline 0 & $28.79 a$ & $28.85 a$ & $28.70 \mathrm{a}$ & $28.59 a$ & $28.56 \mathrm{a}$ & $28.51 \mathrm{a}$ & $28.47 \mathrm{a}$ & $28.42 \mathrm{a}$ \\
\hline 5 & $28.01 \mathrm{~b}$ & $28.11 b$ & $28.17 \mathrm{~b}$ & $28.13 b$ & $28.09 \mathrm{~b}$ & $28.06 b$ & $28.09 \mathrm{~b}$ & $28.10 \mathrm{~b}$ \\
\hline 15 & $26.58 \mathrm{c}$ & $25.45 c$ & $27.08 \mathrm{c}$ & $27.08 \mathrm{c}$ & $27.11 \mathrm{c}$ & $27.15 c$ & $27.12 \mathrm{c}$ & $27.17 \mathrm{c}$ \\
\hline 20 & $29.07 \mathrm{a}$ & $29.21 \mathrm{a}$ & $28.74 a$ & $28.72 \mathrm{a}$ & $28.70 \mathrm{a}$ & $28.71 \mathrm{a}$ & $28.63 \mathrm{a}$ & $28.62 \mathrm{a}$ \\
\hline F-ratio & $* *$ & $* *$ & $* *$ & $* *$ & $* *$ & $* *$ & $* *$ & $* *$ \\
\hline
\end{tabular}

Note: Figures in the same column followed by the same lower case letter are not significantly different analyzed by DMRT at 95\% significance. $* *$ : Significant at $99 \%$

The effect of block on the height of sugarcane was significant. Table 2 shows that during the first month, there was no significant block effect. However, from the second month, the height of sugarcane in Block 1 near the canal was higher than in the far block. In particular, the height of cane compared between Blocks 1 and 4 differed by $15.13 \%$.

Tillering of sugarcane: There were not significantly different numbers of tillering among treatments in all months except for months 6 and 7. The numbers of tillering was quite low, with an average of less than two tillers (Table 3). In addition, tillering of the sugarcane in all blocks did not seem to be different.

Stalk diameter of sugarcane: Stalk diameters of sugarcane were significantly affected by compaction
(Table 4). Stalks in plots with 5 and $15 \mathrm{NpC}$ were smaller in diameter when compared with the ones in plots with $0 \mathrm{NpC}$. Contradictory results were recorded for the stalks in plots with $20 \mathrm{NpC}$, which were not significantly different from the ones in plots with 0 NpC. This was similar to the trend that appeared in the height of sugarcane. Stalk diameter was also different among blocks. Block 1 had the largest stalk diameter, while Block 4 had the smallest (Table 5).

Brix of sugarcane: The Brix of cane was measured using a hand refractometer from eight months age onwards. Brix increased monthly and was greatest at 11 months (Table 6). From the results in Table 6, soil compaction seemed to have no significant effect on Brix. 
Am. J. Agri. \& Biol. Sci., 5 (3): 269-273, 2010

Table 5: Average stalk diameter of sugarcane by block

\begin{tabular}{|c|c|c|c|c|c|c|c|c|}
\hline \multirow[b]{2}{*}{ Block } & \multicolumn{8}{|c|}{ Stalk diameter at month $(\mathrm{cm})$} \\
\hline & 5 & 6 & 7 & 8 & 9 & 10 & 11 & 12 \\
\hline$\overline{1}$ & $30.00 \mathrm{a}$ & $31.00 \mathrm{a}$ & $29.47 \mathrm{a}$ & $29.31 \mathrm{a}$ & $29.23 a$ & $29.17 \mathrm{a}$ & $29.02 \mathrm{a}$ & $29.01 \mathrm{a}$ \\
\hline 2 & $28.11 \mathrm{~b}$ & $26.25 \mathrm{c}$ & $27.85 \mathrm{c}$ & $27.92 \mathrm{c}$ & $27.94 b$ & $27.95 b$ & $28.03 b$ & $28.03 b$ \\
\hline 3 & $27.50 \mathrm{c}$ & $28.38 \mathrm{~b}$ & $28.34 \mathrm{~b}$ & $28.29 b$ & $28.26 \mathrm{~b}$ & $28.26 \mathrm{~b}$ & $28.17 b$ & $28.15 b$ \\
\hline 4 & $26.65 d$ & $26.85 b$ & $26.95 \mathrm{~d}$ & $26.97 d$ & $27.02 \mathrm{c}$ & $27.05 \mathrm{c}$ & $27.12 \mathrm{c}$ & $27.14 \mathrm{c}$ \\
\hline F-ratio & $* *$ & $* *$ & $* *$ & $* *$ & $* *$ & $* *$ & $* *$ & $* *$ \\
\hline
\end{tabular}

Note: Figures in the same column followed by the same lower case letter are not significantly different analyzed by DMRT at $95 \%$ significance. *: Significant at $95 \%$; *: Significant at $99 \%$

Table 6: Average percentage Brix of sugarcane in plots with different soil compaction treatments

\begin{tabular}{|c|c|c|c|c|c|}
\hline \multirow[b]{2}{*}{$\mathrm{NpC}$} & \multicolumn{5}{|c|}{ Brix at month (\%) } \\
\hline & 8 & 9 & 10 & 11 & 12 \\
\hline$\overline{0}$ & 16.32 & 19.8 & 19.64 & 20.26 & $17.18 \mathrm{~b}$ \\
\hline 5 & 16.85 & 19.26 & 19.08 & 19.54 & $18.36 \mathrm{ab}$ \\
\hline 15 & 16.94 & 18.86 & 19.42 & 20.38 & $18.43 \mathrm{ab}$ \\
\hline 20 & 16.79 & 19.49 & 19.75 & 20.33 & $19.56 a$ \\
\hline F-ratio & ns & $\mathrm{ns}$ & ns & ns & $*$ \\
\hline
\end{tabular}

Note: Figures in the same column followed by the same lower case letter are not significantly different analyzed by DMRT at $95 \%$ significance. ns: Not significant; *: Significant at $95 \%$

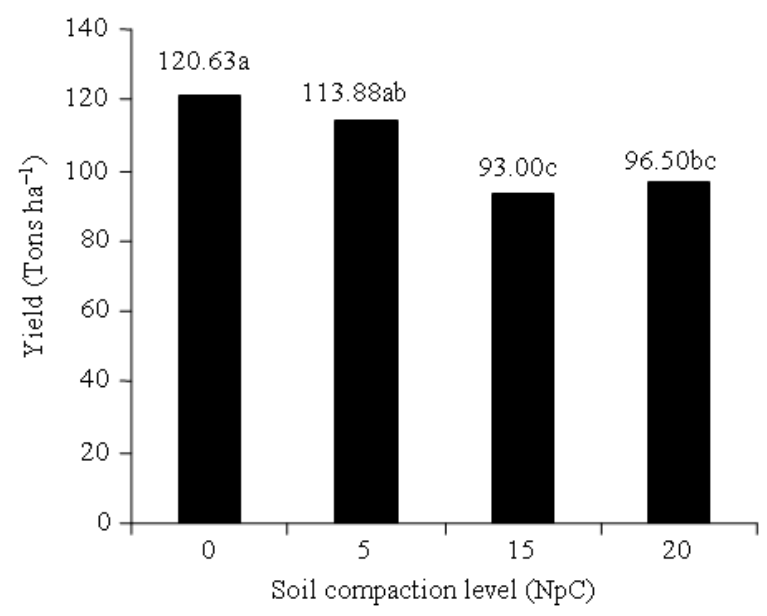

Fig. 2: Relationship between soil compaction level and yield

Yield of sugarcane: The sugarcane was harvested when it was 12 months old and the yield measured. Figure 2 shows the average yield from plots subjected to different levels of soil compaction. The plots with $0 \mathrm{NpC}$ had the highest yields, whereas the plots with $15 \mathrm{NpC}$ produced the lowest yields. Soil compaction significantly affected the yield, with a reduction up to $22.9 \%$, from $120.63-93.00$ tons $\mathrm{ha}^{-1}$ in the plots with 0 and $15 \mathrm{NpC}$, respectively.

Root distribution of sugarcane: Investigation of the root distribution of sugarcane showed different patterns in plots with different levels of soil compaction. Good distribution and deep rooting were found in plots with $0 \mathrm{NpC}$, whereas there was poor distribution and shallow rooting in plots subjected to soil compaction. The shallowest rooting existed in plots with $20 \mathrm{NpC}$, but these plots seemed to have a greater amount of superficial rooting.

\section{DISCUSSION}

Generally, soil compaction at any level affected the growth of sugarcane when compared to the control plots. Bakker (1999) explained that the development and distribution of the sugarcane root system depended on the variety, soil aeration, moisture availability and soil compaction. Soil compaction broke continuous pores and destroyed the structure of the soil. Roots could not find an opportunity to penetrate to any depth, as shown in the plots with 5, 15 and $20 \mathrm{NpC}$. Restriction of roots might have limited the fertilizer uptake in these plots, which resulted in a reduction of growth in terms of height and diameter of the sugarcane.

The effect of soil compaction was apparent from the first stage of germination as can be seen by the lowest height of sugarcane being in plots having 20 $\mathrm{NpC}$ in the first month while the others showed comparatively similar heights. This might have been because the bottom of the groove seemed to have the highest compaction zone for plots with $20 \mathrm{NpC}$, which caused high mechanical impedance to root growth. Consequently, a specific pattern of the root distribution of sugarcane in the plots with $20 \mathrm{NpC}$ was generated. Shallow rooting was obvious in the many lodged canes in the plots with $20 \mathrm{NpC}$ during last 2 months. There were greater numbers of superficial roots near the surface. Superficial roots near the surface facilitated fertilizer and water uptake compared with plants in the plots with 5 or $15 \mathrm{NpC}$. Therefore, the average height of sugarcane in plots with $20 \mathrm{NpC}$ was comparatively higher than in the plots with 5 or $15 \mathrm{NpC}$, from the third month. 
Normally, cane tillering starts around 40 days after planting and may last up to 120 days, with the maximum tiller population reached around 90-120 days after planting (Bakker, 1999). In the current experiment, tillering started quite late and there were not many tillers. The effects of soil compaction on tillering of sugarcane were not apparent in this experiment. One of the causes might be that the low tillering is a characteristic of the K84-200 sugarcane cultivar. However, some research on similar plants reported that soil compaction had affected tillering. Wallace (1987) concluded that compaction significantly reduced tillering of bunchgrass.

Brix should have been highest at month 12 , but in fact, it decreased from a maximum in month 11 in all treatments. In practice, watering is not applied before harvesting in order to increase the Brix, because high water and high temperature result in a reduction in the Brix. However, in this experiment, there was rain during month 12 and a reduction in the Brix resulted in this month.

Even though the height and diameter of stalks in plots with $20 \mathrm{NpC}$ were somewhat greater, there was a lower number of stalks, which overall resulted in no significant difference in the yields compared to plots with 5 and $15 \mathrm{NpC}$ (Fig. 2). The overwatering that resulted in Block 1 at the furrow irrigation head may have had an alleviating effect on the impact of soil compaction on the growth of sugarcane in that block. Moreover, the low liquid limit of the loam soil may have helped to alleviate soil compaction effect.

\section{CONCLUSION}

Based on the results of this research:

- Soil compaction affected the height and diameter of sugarcane

- There was no significant effect of soil compaction on tillering and Brix of sugarcane

- The yield of sugarcane reduced by $22.9 \%$ in plots compacted with 15 tractor passages when compared with the control plot

- Root distribution seemed to be restricted in plots subjected to soil compaction

- An interesting phenomenon was the soil compaction alleviation resulting from heavier watering

\section{ACKNOWLEDGEMENT}

The researchers gratefully acknowledge the Thai Research Fund (TRF) for financial support under project number PDF-68-2544.

\section{REFERENCES}

Alakukku, L. and P. Elonen, 1995. Long-term effects of a single compaction by heavy field traffic on yield and nitrogen uptake of annual crops. Soil Tillage Res., 37: 141-152. DOI: 10.1016/01671987(95)00503-X

Bakker, H., 1999. Sugarcane Cultivation and Management. 1st Edn. Springer, New York, USA., ISBN: 13: 978-0306461194, pp: 706.

CAI., 2008. Agricultural Statistics of Thailand, Crop Year 2008. Centre for Agricultural Information, Office of Agricultural Economics, Ministry of Agriculture and Cooperatives, Bangkok, Thailand, pp: 169.

http://www.oae.go.th/download/journal/yearbook5 $0 . p d f$

Grange, I., P. Prammanee and P. Prasertsak, 2005. Comparative analysis of different tillage systems used in sugarcane (Thailand). AFBM J., 2: 46-50. http://www.csu.edu.au/faculty/science/saws/afbmn etwork/afbmjournal/volume2/number1/secure/AFB MJournal_v02_n01_06_Grange_et_al.pdf

Nasr, H.M. and F. Selles, 1995. Seedling emergence as influenced by aggregate size, bulk density and penetration resistance of the seedbed. Soil Tillage Res., 34: 61-76. DOI: 10.1016/01671987(94)00451-J

Ngunjiri, G.M.N. and J.C. Siemens, 1995. Wheel traffic effects on corn growth. Trans. ASAE., 38: 691-699. http://asae. frymulti.com/abstract. asp?aid $=27882 \& \mathrm{t}=1$

Wallace, L.L., 1987. Effects of clipping and soil compaction on growth, morphology and mycorrhizal colonization of Schizachyrium scoparium, a $\mathrm{C} 4$ bunchgrass. Oecologia, 72: 423-428. DOI: 10.1007/BF00377574 